\title{
Response and productivity of Garlic (Allium Sativum $L$.) by different levels of potassium fertilizer in farm soils
}

\author{
Md. Abu Sayem Jiku', Md. Alimuzzaman², Ashutus Singha ${ }^{1 *}$ (D), Md. Arifur Rahaman', Ratan Kumar Ganapati ${ }^{3}$, \\ Md. Ashraful Alam ${ }^{4}$ and Shata Rupa Sinha ${ }^{5}$
}

\begin{abstract}
Background: Garlic (Allium sativum L.) has been used as a medicine throughout ancient and modern history; it has been taken to prevent and treat a wide range of conditions and diseases. In Bangladesh, the demand for garlic increases day by day, but on the other hand, due to a shortage of land, production of garlic is not up to the mark. However, to solve the problem, a pot culture experiment was conducted the net house of the Department of Agricultural Chemistry, Bangladesh Agricultural University, Mymensingh during the period of November 2007 to March 2008 to examine the effect of potassium (K) on the growth, yield, nutrient content, and its uptake by garlic.

Results: In this study, six levels of K viz. 0, 100, 125, 150, 175, 200, $250 \mathrm{~kg} \mathrm{ha}^{-1}$ were used as treatments. All the parameters, i.e., plant height, number of leaves plant ${ }^{-1}$, fresh and dry weights of leaves ( $\mathrm{g} \mathrm{plant}^{-1}$ ), fresh and dry weights of bulb ( g plant $^{-1}$ ), bulb diameter, and number of cloves bulb ${ }^{-1}$ significantly varied due to different doses of K application. The maximum total yield and size of garlic bulb were obtained with potassium application at 200 $\mathrm{kg} \mathrm{ha}^{-1}$. Potassium at $200 \mathrm{~kg} \mathrm{ha}^{-1}$ produced the highest fresh and dry weights of bulbs and leaves, diameter, moisture content, number of cloves, and yield as compared to the other treatments. The uptake of nutrients like $\mathrm{N}$, $\mathrm{P}, \mathrm{K}, \mathrm{S}, \mathrm{Ca}, \mathrm{Mg}, \mathrm{B}$, and $\mathrm{Na}$ significantly varied due to the application of different doses of $\mathrm{K}$. The highest contents and nutrient uptake of $\mathrm{N}, \mathrm{P}, \mathrm{K}, \mathrm{S}, \mathrm{Ca}, \mathrm{Mg}, \mathrm{B}$, and Na were found with potassium application at $200 \mathrm{~kg} \mathrm{ha}^{-1}$.
\end{abstract}

Conclusions: The overall results suggested that the yield of garlic increased with increasing potassium fertilizer, where $\mathrm{K}$ application at $200 \mathrm{~kg} \mathrm{ha}^{-1}$ is suitable for obtaining maximum yield.

Keywords: Physiology, Potassium, Yield, Garlic (Allium Sativum L.)

\section{Introduction}

Garlic (Allium sativum L.) is one of the most ancient spices having pungent characteristics of the Allium genus (Bose and Som 1990). Garlic is a member of the family Liliaceae. It is the second most widely used spices crop of Allium after onion (Purseglove 1985). The major garlic-producing countries in the world are China, India, Korea, Spain, Russian Federation, Egypt, Myanmar, Thailand, and the USA (FAO 2004 and Innvista 2005). One million hectares of garlic produce about 10 million metric tons of garlic globally each year, according to the

\footnotetext{
* Correspondence: ashutus.iwm@sau.ac.bd

${ }^{1}$ Institute of Environment and Sustainable Development in Agriculture,

Chinese Academy of Agricultural Science, Beijing, China

Full list of author information is available at the end of the article
}

United Nations Food and Agriculture Organization (FAO 2004). The average yield of garlic in Bangladesh is very low as compared to other countries of the world (FAO 2004).

In Bangladesh, the demand for garlic increases day by day because of gradual increase in utilization in different ways and means. It is not possible to increase the area of crop due to the limitation of land. So, the way to solve this problem is by increasing the yield per hectare and this can be done in many ways. The most important is by using the proper doses of fertilizers. The production of garlic in Bangladesh is still in the hands of marginal farmers. Its production technology has not yet been standardized. Moreover, necessary in-depth knowledge and information regarding the use of potassium fertilizer 
in garlic production under Bangladesh conditions are scanty. The judicious application of fertilizer may enhance bulb yield significantly.

Potassium (K) is a vital nutrient for increasing garlic yields. Proper application rates and timing are critical for generating a yield or quality response. As crop yield increase, the amount of $\mathrm{K}$ required also increases, along with all other nutrients (Mendez et al. 2001). Garlic demand for $\mathrm{K}$ ranges from 125 to $180 \mathrm{~kg} \mathrm{~K}_{2} \mathrm{O} \mathrm{ha}{ }^{-1}$ (Bertoni 1988; Zink 1963). Total bulb yield was increased with increasing level of $\mathrm{K}$ application (Sing and Verma 2001; Sharma et al. 2003; Bybordi and Malakouti 2003; 2003; Linx and Niwuzhang 1997; Jiang et al. 1998 and Melzer et al. 1999). Moreover, Al-Moshile (2001) reported that potassium application at $150 \mathrm{~kg} \mathrm{fed}^{-1}$ reduced the unmarketable bulb yield as compared to control. On the other hand, Sharma (1992) reported that the application of a moderate level of $K\left(40 \mathrm{~kg} \mathrm{fed}^{-1}\right)$ significantly increased bulb yield but adding the high level $\left(80 \mathrm{~kg} \mathrm{~K} \mathrm{fed}^{-1}\right)$ had no further effect. Potassium helps in the root development and increasing the efficiency of leaf in the manufacture of sugar and starch. It is essential for the translocation of sugars. It exerts a balancing role on the effect on both nitrogen and phosphorus. Consequently, it is especially important in multi-nutrient fertilizer application (Brady 1995). Moreover, Mahmoud $R$ (1999) reported that bulb height, diameter, and weight were increased with an increasing level of $\mathrm{K}$ application up to $300 \mathrm{~kg}$ potassium sulfate feddan ${ }^{-1}$.

Thus this research aimed to study the effect of $\mathrm{K}$ addition on growth, bulb yield, and quality of garlic. Considering the above facts, the present investigation was undertaken with the following objectives to observe the effect of different levels of $K$ fertilizer on the growth, yield, and quality of garlic and to determine the impact of different levels of $\mathrm{K}$ on the nutrient content and their uptake by garlic.

\section{Materials and methods}

\section{Experimental location and collection of sample}

The pot experiment was conducted in the net house of the Department of Agricultural Chemistry, Bangladesh Agricultural University, Mymensingh from November 2007 to March 2008. Kharif season (April to September) and Rabi season (October to March) were considered and details of climatic condition viz., monthly average temperature, total rainfall, relative humidity, and sunshine were recorded (Appendix in Table 5). A local cultivar of the garlic "Kushtia" was used as a test crop in this experiment. Bulbs were collected from Kushtia district of Bangladesh. The cloves of uniform size were selected for planting. The average weight and diameter of the cloves were $1.5-2.0 \mathrm{~g}$ and $0.8-1.0 \mathrm{~cm}$, respectively. Soil was collected from the Horticulture Field, Bangladesh
Agricultural University, Mymensingh. The initial surface soil samples were collected $15 \mathrm{~cm}$ depth and the collected soil samples were air-dried and sieved with $2 \mathrm{~mm}$ sieve.

\section{Experimental design and treatments}

This experiment was conducted in a completely randomized design (CRD) and total of seven treatments were used in three replicates. Collected soil samples were mixed with potassium (K) using seven different pre-treatments as described below, K0: $0 \mathrm{~kg} \mathrm{~K}$ (only soil), K100: $100 \mathrm{~kg} \mathrm{~K}, \mathrm{~K} 125: 125 \mathrm{~kg} \mathrm{~K}, \mathrm{~K} 150: 150 \mathrm{~kg} \mathrm{~K}$, K175: $175 \mathrm{~kg}$ k, K200: $200 \mathrm{~kg} \mathrm{K,} \mathrm{K250:} 250 \mathrm{~kg}$ K per hectare respectively. Each pot contained a total amount of 7 $\mathrm{kg}$ of soil. The dimension of the used plastic pots was 35 $\mathrm{cm}$ of height with a top diameter of $30 \mathrm{~cm} . \mathrm{N}, \mathrm{P}, \mathrm{S}, \mathrm{B}$, and $\mathrm{Zn}$ were applied at $55 \mathrm{~kg} \mathrm{~N}, 53 \mathrm{~kg} \mathrm{P}, 35 \mathrm{~kg} \mathrm{~S}, 1 \mathrm{~kg}$ $\mathrm{B}, 4 \mathrm{~kg} \mathrm{Zn}$ per hectare respectively. All kinds of fertilizers were applied to soils before the planting of cloves. Only nitrogen was applied in three splits. First split was applied before planting the cloves and the second split was applied at 30 DAS as well as third split at 60 DAS. Both time fertilizers were applied as broadcast and incorporated into the soil followed by weeding. Seven cloves were planted in each pot. The depth of planting was around $2.5 \mathrm{~cm}$. Frequency of irrigation depends upon the moisture status of the soil. Irrigation was provided in each pot uniformly after the application of nitrogen fertilizer at 90 days after planting (DAP). After the complete emergence of the crop, Rovral at $50 \mathrm{~g}$ mixed with $10 \mathrm{l}$ of water and applied every 15 days later to prevent the attack of diseases. Extra care was taken so that no bulb was injured during lifting.

\section{Plant sample collection}

Five plants were randomly selected from each pot. The following parameters were considered such as plant height, and a number of green leaves per plant was measured at 30, 45, 60, 75, 90, 105 DAP. The Fresh weight of leaves of were weighted. The fresh weight of bulb was taken from five sample bulb and calculated the average value of individual bulb. Bulb diameter was measured with slide calipers from the five sample plants and calculated the average value. Fresh leaves and bulbs were kept in an oven at $70{ }^{\circ} \mathrm{C}$ until constant weight and measured the dry weight. The number of cloves of sample bulbs were counted and average number of cloves was calculated. Moisture content was calculated according to the following formula:

$$
\% \text { Moisture Content }=\frac{W_{1}-W_{2}}{W_{1}} \times 100
$$

Where $W_{1}$ is the initial weight of sample and $W_{2}$ is the final weight of sample. 


\section{Soil characterization}

Soil $\mathrm{pH}$ was measured by $\mathrm{pH}$ meter. The soil to water suspension ratio was 1 to 2.5 (w:v) (Jackson 1973) and EC of the soil was measured by EC meter using soil to water suspension which was 1 to 5 (w:v) proportions (Jackson 1973). Organic carbon was determined by the wet oxidation method as described by Black (1965) and the organic matter content was calculated by multiplying the percent organic carbon with the Van Bemmelen factor of 1.73 (Piper 1950). Total nitrogen in initial soil was determined by micro-kjeldahl method. Digestion by titration followed by the Page et al. (1982). The percentage of nitrogen in the soil was calculated by the following formula:

$$
\% \text { Total nitrogen }=\frac{(V-B \times N \times 14.01)}{W \times 1000} \times 100
$$

Where $V$ is the volume of $0.01 \mathrm{NH}_{2} \mathrm{SO}_{4}$ nitrated for sample $(\mathrm{ml}), B$ is the digested blank titration volume (ml), $N$ is the normality of $\mathrm{H}_{2} \mathrm{SO}_{4}$ solution, 14.01 is the atomic weight of N, $R$ is the ratio of total volume of the digest and the volume of digest used for distillation, and $W$ is the weight of air-dry soil.

\section{Plant samples characterization}

Phosphorus was estimated colorimetrically by the stannous chloride method as described by Jackson (1973). The content of potassium in the plant samples was determined separately with the help of flame emission spectrophotometer using appropriate filters as described as Ghosh et al. (1983). The concentration of sulfur in the extract was estimated turbidimetrically with the help of a spectrophotometer as described as Wolf (1982). Calcium content in plant samples was determined by the complexometric method of titration using Na2EDTA as a complexing agent at $\mathrm{pH} 12$ where calcon was used as an indicator (Page et al. 1982). Magnesium was determined by the complexometric method of titration using Na2EDTA as a complexing agent at pH 10 where Eriochrome Black T (EBT) was used as an indicator (Page et al. 1982). Boron concentration of the extract was determined colorimetrically as described by Page et al. (1982). The content of $\mathrm{Na}$ in plant extract was determined by the use of flame photometer and the intensity of light emitted by sodium at $589 \mathrm{~nm}$ (Jackson 1973).

\section{Nutrient uptake}

After chemical analyses of plant samples, the nutrient contents were calculated and from the value of nutrient contents, nutrient uptakes were also calculated by the following formula:

$$
\begin{aligned}
& \text { Nutrient Uptake }\left(m g \text { pot }^{-1}\right) \\
& =\frac{\text { Nutrient Content }(\%) \times \text { yield }}{100}
\end{aligned}
$$

\section{Statistical analysis}

Analysis of variance was done following completely randomized design (CRD) with the help of computer package MSTAT developed by Russel (1984). The data were analyzed statistically by $F$ test (Gomez and Gomez 1984). The mean differences of the treatments were adjusted by least significant difference (LSD) test.

\section{Results}

The physical and chemical properties of the initial soil have been presented in Table 1.

\section{Effect of $\mathrm{K}$ on growth, yield, and quality of garlic}

The result of $\mathrm{K}$ on yield and yield contributing characters of garlic have been presented in Tables 2 and 4 .

\section{Plant height and leaves per plant}

Potassium had a significant effect on plant height at different DAP except at 30 and 45 DAP (Appendix in Table 6). The highest plant height was $55.77 \mathrm{~cm}$ found in $105 \mathrm{DAP}$ at $200 \mathrm{~kg} \mathrm{~K} / \mathrm{ha}$ and the lowest value was $48.96 \mathrm{~cm}$ found in control (Fig. 1a).

Effect of different doses of $\mathrm{K}$ on number of leaves per plant at 60,70, 90, 105 DAP was found statistically significant except at 30 and 45 DAP (Appendix in Table 7). At 105 DAP, the maximum number of leaves were 7.11 produced with $200 \mathrm{~kg} \mathrm{~K} / \mathrm{ha}$, while the control was 6.07 (Fig. 1b).

\section{Fresh and dry weight of individual bulb}

Different levels of $\mathrm{K}$ exerted significant influence on the fresh and dry weight of individual bulb (Appendix in Table 8 ). Bulb weight increased gradually with the increase of $\mathrm{K}$ up to the level of $200 \mathrm{~kg} \mathrm{~K} / \mathrm{ha}$ and then after decreased with increase of $K$ (Table 2). The highest

\begin{tabular}{|c|c|c|c|c|}
\hline \multicolumn{5}{|c|}{ Physical characteristics } \\
\hline $\begin{array}{l}\text { Sand \% (0.2- } \\
0.02 \mathrm{~mm})\end{array}$ & \multicolumn{2}{|c|}{$\begin{array}{l}\text { Silt \% (0.02- } \\
0.002 \mathrm{~mm})\end{array}$} & $\begin{array}{l}\text { Clay \% }(<0.002 \\
\mathrm{mm})\end{array}$ & Textural class \\
\hline 31 & \multicolumn{2}{|l|}{62} & 7 & Silty loam \\
\hline \multicolumn{5}{|c|}{ Chemical characteristics } \\
\hline $\begin{array}{ll}\mathrm{pH} & \mathrm{EC} \\
& (\mathrm{dS} \mathrm{m}-1)\end{array}$ & $\begin{array}{l}\mathrm{OC} \\
(\%)\end{array}$ & $\begin{array}{l}\text { TN } \\
(\%)\end{array}$ & $\begin{array}{l}\text { Available P ( } \mu \mathrm{g} \\
\mathrm{g}^{-1} \text { ) }\end{array}$ & $\begin{array}{l}\text { Exchangeable } \mathrm{K}(\mathrm{cmol} \\
\mathrm{kg}^{-1} \text { ) }\end{array}$ \\
\hline $6.7 \quad 6.64$ & 0.845 & 1.75 & 0.13 & 12.8 \\
\hline
\end{tabular}
value of fresh weight bulb was $11.56 \mathrm{~g}$ obtained from

Table 1 Physical and chemical properties of the soil 
Table 2 Effect of potassium on growth, yield and quality of garlic

\begin{tabular}{|c|c|c|c|c|c|c|c|c|c|}
\hline \multirow[t]{2}{*}{ Treatment } & \multicolumn{2}{|c|}{ Fresh weight plant ${ }^{-1}(\mathrm{~g})$} & \multicolumn{2}{|c|}{ Dry weight plant ${ }^{-1}(\mathrm{~g})$} & \multicolumn{2}{|c|}{ Moisture content (\%) } & \multirow{2}{*}{$\begin{array}{l}\text { Diameter } \\
\text { of bulb } \\
\text { (cm) }\end{array}$} & \multirow{2}{*}{$\begin{array}{l}\text { Cloves } \\
\text { bulb }^{-1} \\
\text { (No.) }\end{array}$} & \multirow{2}{*}{$\begin{array}{l}\text { Yield } \\
\text { pot }^{-1} \\
\text { (g) }\end{array}$} \\
\hline & Bulb & Leaves & Bulb & Leaves & Bulb & Leaves & & & \\
\hline KO & 8.00 & 5.77 & 2.47 & 0.99 & 70.17 & 81.13 & 2.07 & 13.13 & 50.50 \\
\hline K100 & 8.46 & 6.30 & 2.90 & 1.05 & 65.95 & 83.22 & 2.53 & 15.41 & 50.76 \\
\hline K125 & 9.27 & 6.73 & 2.64 & 1.10 & 64.95 & 83.23 & 2.59 & 18.67 & 55.43 \\
\hline K150 & 9.84 & 6.87 & 3.13 & 1.11 & 68.64 & 83.43 & 2.58 & 17.40 & 56.95 \\
\hline K175 & 9.17 & 7.47 & 3.05 & 1.18 & 69.46 & 83.73 & 2.55 & 15.59 & 53.03 \\
\hline K200 & 11.56 & 8.10 & 3.47 & 1.32 & 70.02 & 82.27 & 2.74 & 19.12 & 62.59 \\
\hline K250 & 9.25 & 6.70 & 2.53 & 1.18 & 73.10 & 82.03 & 2.26 & 15.22 & 51.66 \\
\hline LSD & 1.282 & 0.910 & 0.418 & 0.247 & 7.887 & 6.731 & 0.485 & 1.936 & 4.478 \\
\hline Significance & $* *$ & $* *$ & $* *$ & * & * & NS & * & $* *$ & $* *$ \\
\hline CV(\%) & 7.82 & 7.59 & 8.28 & 12.62 & 6.54 & 4.64 & 11.19 & 6.76 & 4.70 \\
\hline
\end{tabular}

* Significant at $5 \%$ level of probability, ${ }^{* *}$ significant at $1 \%$ level of probability, NS not significant, LSD least significant difference, CV coefficient of variation

$200 \mathrm{~kg} \mathrm{~K} / \mathrm{ha}$ and the lowest value was $8 \mathrm{~g}$ produced by control as well as fry weight of bulb.

\section{Moisture content of bulb}

A significant variation in moisture content of bulb was found due to the application of different levels of $\mathrm{K}$ fertilizer. Moisture content (\%) was recorded from all the treatments and the results were shown on Appendix in Table 8. The maximum moisture content of bulb was recorded from the pots treated with $250 \mathrm{~kg}$ $\mathrm{k} /$ ha $(73.10 \%)$. The minimum moisture content was recorded from the pots treated with $125 \mathrm{~kg} \mathrm{k} / \mathrm{ha}$ (64.95\%) (Table 2).

\section{Fresh and dry weight of leaves}

Significant differences were observed in fresh and dry weight of leaves among the different $\mathrm{K}$ levels at harvest (Appendix in Table 8). The maximum fresh weight of leaves per plant was observed at $200 \mathrm{~kg} \mathrm{~K} / \mathrm{ha}$, and the minimum fresh weight of leaves per plant was found at control treatment as well as dry weight of leaves (Table 2).

\section{Moisture content of leaves}

Different levels of $\mathrm{K}$ fertilizer showed no significant effect of moisture content of leaves (Appendix in Table 8). Moisture content was recorded from all the treatments and the results are shown in Table 2 . Maximum moisture content $(83.73 \%)$ was recorded from $175 \mathrm{~kg} \mathrm{k} / \mathrm{ha}$ and the minimum moisture content (81.13\%) from $\mathrm{kg} \mathrm{k} / \mathrm{ha}$.

\section{Bulb diameter and number of cloves per bulb}

There was a significant effect of different levels of $\mathrm{K}$ on bulb diameter (Appendix in Table 8). The highest bulb diameter $(2.74 \mathrm{~cm})$ was obtained in the treatment of 200 $\mathrm{kg} \mathrm{K} / \mathrm{ha}$, while the lowest bulb diameter $(2.07 \mathrm{~cm})$ was found in the control treatment (Table 2). Optimum $\mathrm{K}$

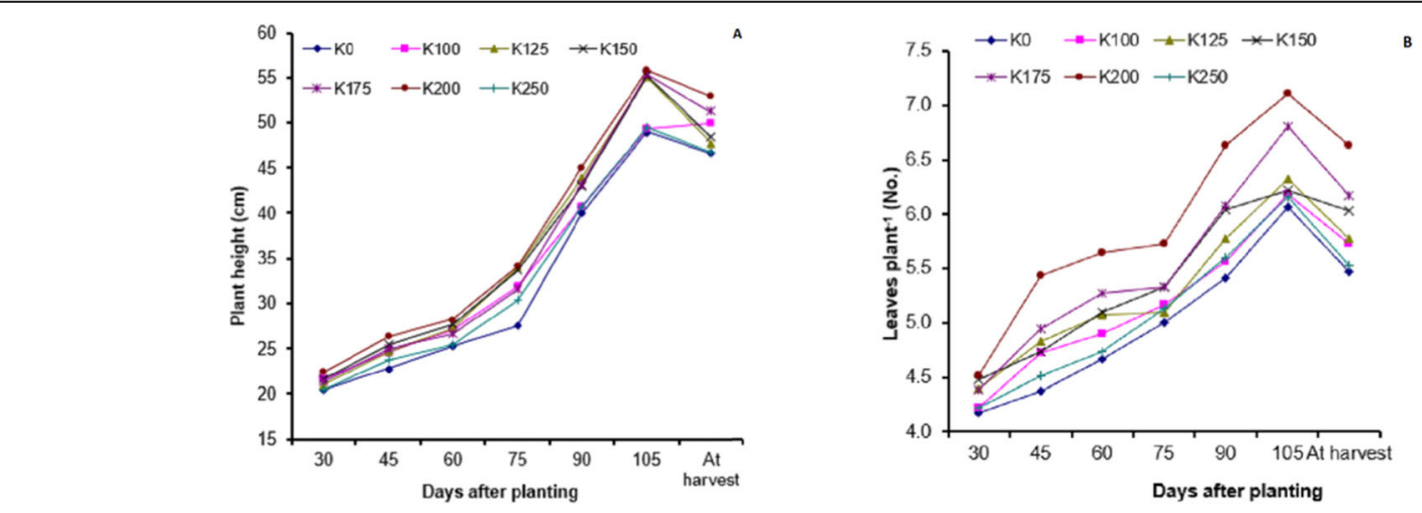

Fig. 1 effects of potassium on a plant height and $\mathbf{b}$ plant leaves of garlic at different days after planting. K0: 0 kg K (only soil), K100: 100 kg K, K125: 125 kg K, K150: 150 kg K, K175: 175 kg K, K200: 200 kg K, K250: 250 kg K 


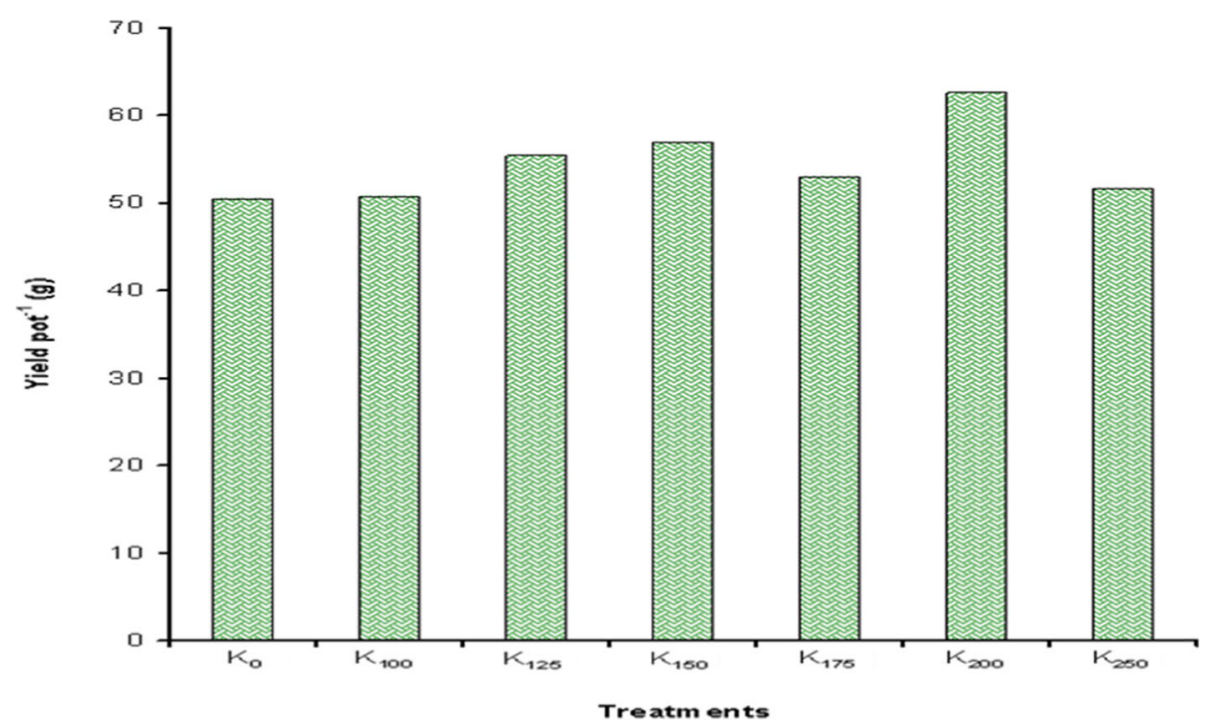

Fig. 2 Effects of potassium on the yield of garlic. K0: 0 kg K (only soil), K100: 100 kg K, K125: 125 kg K, K150: 150 kg K, K175: 175 kg K, K200: 200 $\mathrm{kg} \mathrm{K}, \mathrm{K} 250: 250 \mathrm{~kg} \mathrm{~K}$

nutrient supplied from the $200 \mathrm{~kg} \mathrm{k} / \mathrm{ha}$ treatment possibly favored plant growth and development, thus producing wider bulb.

There was a significant variation in the number of cloves per bulb due to the effect of different $\mathrm{K}$ levels (Appendix in Table 8). The highest average number of cloves was obtained in plants grown with $200 \mathrm{~kg} \mathrm{~K} / \mathrm{ha}$ and the lowest number of cloves was found from the control treatment.

\section{Bulb yield}

Different doses of $K$ showed a significant effect on the yield of bulb per pot (Appendix in Table 8). Application of $200 \mathrm{~kg} \mathrm{~K} / \mathrm{ha}$ produced the highest yield $62.59 \mathrm{~g}$, and the control treatment gave the lowest yield of $50.50 \mathrm{~g}$ (Fig. 2). It was observed that the yield per pot showed a general trend of gradual increase with the increasing level of $\mathrm{K}$ up to $200 \mathrm{~kg} \mathrm{k} / \mathrm{ha}$ and after it was decreased. Talukder et al. (2002) and El-Bassiony (2006) obtained the highest yield by applying $\mathrm{K}$ at $200 \mathrm{~kg} \mathrm{k} / \mathrm{ha}$. The plant raised with $200 \mathrm{~kg} \mathrm{~K} / \mathrm{ha}$ received sufficient potash in this experiment. As a result, their growth was enhanced and ultimately, yield was increased.

The effect of different levels of $\mathrm{K}$ fertilizer on $\mathrm{N}$ content in bulb of garlic was statistically significant at $1 \%$ level of probability (Appendix in Table 9). The $\mathrm{N}$ content in bulb ranged from 1.50 to $2.50 \%$. The highest concentration of $\mathrm{N}$ in bulb was observed in 200

Table 3 Effect of different levels of $\mathrm{K}$ on $\mathrm{N}, \mathrm{P}, \mathrm{K}, \mathrm{S}, \mathrm{Ca}, \mathrm{Mg}, \mathrm{B}$, and $\mathrm{Na}$ contents in bulb and leaves of garlic

\begin{tabular}{|c|c|c|c|c|c|c|c|c|c|c|c|c|c|c|c|c|}
\hline \multirow[t]{2}{*}{ Treatment } & \multicolumn{2}{|l|}{ N (\%) } & \multicolumn{2}{|l|}{ P (\%) } & \multicolumn{2}{|l|}{$\mathrm{K}(\%)$} & \multicolumn{2}{|l|}{$S(\%)$} & \multicolumn{2}{|c|}{ Ca (\%) } & \multicolumn{2}{|c|}{$\mathrm{Mg}(\%)$} & \multicolumn{2}{|c|}{$B(\mu g g-1)$} & \multicolumn{2}{|c|}{$\mathrm{Na}(\%)$} \\
\hline & Bulb & Leaves & Bulb & Leaves & Bulb & Leaves & Bulb & Leaves & Bulb & Leaves & Bulb & Leaves & Bulb & Leaves & Bulb & Leaves \\
\hline KO & 1.50 & 3.10 & 0.15 & 0.25 & 2.10 & 2.48 & 0.43 & 0.25 & 0.62 & 1.00 & 0.20 & 1.11 & 21.25 & 26.24 & 0.10 & 0.12 \\
\hline K100 & 1.62 & 3.20 & 0.18 & 0.28 & 2.25 & 2.63 & 0.46 & 0.27 & 0.63 & 1.10 & 0.23 & 1.12 & 21.61 & 26.50 & 0.13 & 0.13 \\
\hline K125 & 1.72 & 3.32 & 0.21 & 0.30 & 2.50 & 2.80 & 0.47 & 0.28 & 0.66 & 1.29 & 0.24 & 1.14 & 21.96 & 26.82 & 0.14 & 0.14 \\
\hline K150 & 1.94 & 3.42 & 0.24 & 0.32 & 2.62 & 3.08 & 0.47 & 0.32 & 0.68 & 1.36 & 0.23 & 1.15 & 22.31 & 27.16 & 0.15 & 0.16 \\
\hline K175 & 2.40 & 3.62 & 0.32 & 0.38 & 2.74 & 3.25 & 0.48 & 0.47 & 0.72 & 1.38 & 0.24 & 1.16 & 22.66 & 27.82 & 0.16 & 0.17 \\
\hline K200 & 2.50 & 4.09 & 0.35 & 0.45 & 2.82 & 3.87 & 0.52 & 0.50 & 0.78 & 1.55 & 0.25 & 1.18 & 23.37 & 28.17 & 0.17 & 0.20 \\
\hline K250 & 2.10 & 3.55 & 0.27 & 0.27 & 2.70 & 2.97 & 0.50 & 0.47 & 0.74 & 1.28 & 0.23 & 1.15 & 21.95 & 27.55 & 0.15 & 0.18 \\
\hline LSD & 0.06 & 0.336 & 0.070 & 0.429 & 0.095 & 0.110 & 0.067 & 0.391 & 0.055 & 3.485 & 0.055 & 0.039 & 0.287 & 0.192 & 0.05 & 0.060 \\
\hline Significance & $* *$ & $* *$ & $* *$ & $* *$ & $* *$ & $* *$ & $* *$ & $* *$ & $* *$ & $* *$ & NS & * & $* *$ & $* *$ & * & * \\
\hline CV(\%) & 1.94 & 5.51 & 11.23 & 6.03 & 2.29 & 2.14 & 5.14 & 5.56 & 3.38 & 3.96 & 10.41 & 2.13 & 0.74 & 0.40 & 15.84 & 17.06 \\
\hline
\end{tabular}

* Significant at $5 \%$ level of probability, ${ }^{* *}$ significant at $1 \%$ level of probability, NS not significant 
$\mathrm{kg} \mathrm{k/ha} \mathrm{(Table} \mathrm{3).} \mathrm{Calcium,} \mathrm{sulfur,} \mathrm{sodium} \mathrm{content} \mathrm{in}$ bulb of garlic was statistically significant (Appendix in Table 9), and the highest nutrient concentration in bulb was observed in $200 \mathrm{~kg} \mathrm{k} / \mathrm{ha}$ (Table 3). The results on the concentration of nutrient elements like $\mathrm{N}, \mathrm{P}, \mathrm{K}, \mathrm{Ca}, \mathrm{Mg}, \mathrm{S}, \mathrm{B}$, and $\mathrm{Na}$ in leaves of garlic due to the different levels of $\mathrm{K}$ fertilizers have been presented in Table 3. The results revealed that the content of $\mathrm{N}, \mathrm{P}, \mathrm{K}, \mathrm{Ca}, \mathrm{S}, \mathrm{B}$, and $\mathrm{Na}$ in leaves of garlic varied significantly due to the different levels of $\mathrm{K}$ fertilizers (Appendix in Table 9).

\section{Uptake of different nutrients by garlic bulb}

There was a significant variation in the uptake of nutrient elements like $\mathrm{N}, \mathrm{P}, \mathrm{K}, \mathrm{S}, \mathrm{Ca}, \mathrm{Mg}, \mathrm{B}$, and $\mathrm{Na}$ by garlic bulb due to the effect of different levels of $\mathrm{K}$ fertilizer have been presented in Table 4 and Appendix in Table 10. A significant variation in $\mathrm{N}$ uptake by garlic bulb was observed due to the application of $\mathrm{K}$ at different doses (Table 4 and Appendix in Table 10). The highest $\mathrm{N}$ uptake $\left(86.72 \mathrm{mg}\right.$ pot $^{-1}$ ) was observed in treatment of $200 \mathrm{~kg} \mathrm{k} / \mathrm{ha}$. The lowest $\mathrm{N}$ uptake (36.81 mg pot $^{-1}$ ) was observed in control treatment. As well as phosphorus, potassium uptake by garlic bulb was significant due to the effect of different levels of $\mathrm{K}$ fertilizer application. Data presented in Appendix in Table 10 and Table 4 showed that the variation was higher in $\mathrm{K} 200$ and $\mathrm{K} 0$ treatments. The highest $\mathrm{P}$ uptake was found in $\mathrm{K}$ at $200 \mathrm{~kg} \mathrm{ha}^{-} 1$ and the lowest uptake was found in K0 treatment as well as $\mathrm{K}$ (Table 4). Similar results were observed in $\mathrm{S}, \mathrm{Ca}, \mathrm{Mg}, \mathrm{B}$, and $\mathrm{Na}$. All were statistically significant due to the different application rates of potassium compared to the control and highest results observed in $200 \mathrm{~kg} \mathrm{k} / \mathrm{ha}$.

\section{Uptake of different nutrients by garlic leaves}

This results presented in Table 4 showed that $\mathrm{N}$ uptake by garlic leaves was significantly varied and progressively increased by $\mathrm{K}$ application as compared with control treatment up to a certain level. The highest $\mathrm{N}$ uptake of $53.81 \mathrm{mg}$ per pot was noted in $200 \mathrm{~kg} \mathrm{k} / \mathrm{ha}$, whereas the $\mathrm{P}$ uptake by garlic leaves varied significantly due to different levels of $\mathrm{K}$ application (Appendix in Table 10) and the highest P uptake by leaves was observed at $200 \mathrm{~kg} \mathrm{k} / \mathrm{ha}$ treatment. The $\mathrm{K}$ uptake by garlic leaves was statistically significant with different $\mathrm{K}$ levels and the highest $\mathrm{K}$ uptake was obtained when the crop was fertilized with 200 $\mathrm{kg} \mathrm{K} / \mathrm{ha}$. Application of different levels of $\mathrm{K}$ had a significant effect in $\mathrm{Na}, \mathrm{Ca}, \mathrm{Mg}, \mathrm{B}, \mathrm{S}$, and highest nutrient uptake was obtained when the crop was fertilized with $200 \mathrm{~kg} \mathrm{~K} / \mathrm{ha}$ and the lowest nutrient uptake was in control (K0) treatment.

\section{Discussion}

Garlic (Allium sativum L.) has acquired a reputation in different traditions as a prophylactic as well as a therapeutic medicinal plant. Garlic has played important dietary and medicinal roles throughout history. Among different treatments, the increased plant height at higher dose of $\mathrm{K}$ was probably due to the availability of more nutrients which encouraged more vegetative growth. Same results were found by Talukder (1998), Amin (1998), and El-Bassiony (2006). At 105 DAP, the maximum number of leaves was more produced (7.11) with $200 \mathrm{~kg} \mathrm{~K} /$ ha than the control (6.07) (Fig. 1b). A similar result was also reported by Talukder (1998) and El-Bassiony (2006) who obtained higher leaf number from the same level of $\mathrm{K}$. In this treatment, individual plants got adequate nutrients which helped to increase

Table 4 Effect of different levels of $\mathrm{K}$ on N, P, K, S, Ca, Mg, B and Na uptake by bulb and leaves of garlic

\begin{tabular}{|c|c|c|c|c|c|c|c|c|c|c|c|c|c|c|c|c|}
\hline \multirow[t]{2}{*}{ Treatment } & \multicolumn{2}{|c|}{$N\left(\mathrm{mg} \mathrm{pot}^{-1}\right)$} & \multicolumn{2}{|c|}{$P\left(\mathrm{mg} \mathrm{pot}^{-1}\right)$} & \multicolumn{2}{|c|}{$\mathrm{K}\left(\mathrm{mg} \operatorname{pot}^{-1}\right)$} & \multicolumn{2}{|c|}{$\mathrm{S}\left(\mathrm{mg} \mathrm{pot}^{-1}\right)$} & \multicolumn{2}{|c|}{$\mathrm{Ca}\left(\mathrm{mg} \mathrm{pot}{ }^{-1}\right)$} & \multicolumn{2}{|c|}{$\mathrm{Mg}\left(\mathrm{mg} \operatorname{pot}^{-1}\right)$} & \multicolumn{2}{|c|}{$B\left(\mu g \operatorname{pot}^{-1}\right)$} & \multicolumn{2}{|c|}{$\mathrm{Na}\left(\mathrm{mg} \operatorname{pot}^{-1}\right)$} \\
\hline & Bulb & Leaves & Bulb & Leaves & Bulb & Leaves & Bulb & Leaves & Bulb & Leaves & Bulb & Leaves & Bulb & Leaves & Bulb & Leaves \\
\hline KO & 36.81 & 31.08 & 3.533 & 2.463 & 52.02 & 24.62 & 10.54 & 2.457 & 15.35 & 9.803 & 5.100 & 10.97 & 52.50 & 27.47 & 2.510 & 1.200 \\
\hline K100 & 46.85 & 33.67 & 5.200 & 2.953 & 65.38 & 27.89 & 13.53 & 2.810 & 18.17 & 11.48 & 6.653 & 11.67 & 62.64 & 30.81 & 3.857 & 1.327 \\
\hline K125 & 44.67 & 36.60 & 5.693 & 3.297 & 64.98 & 30.83 & 12.21 & 3.100 & 16.97 & 14.14 & 6.240 & 12.51 & 56.91 & 29.11 & 3.590 & 1.590 \\
\hline K150 & 61.01 & 38.10 & 7.717 & 3.597 & 84.95 & 34.38 & 14.54 & 3.573 & 21.21 & 15.16 & 7.103 & 12.83 & 69.67 & 30.00 & 4.840 & 1.803 \\
\hline K175 & 73.42 & 42.60 & 9.950 & 4.470 & 84.01 & 38.21 & 14.56 & 5.520 & 22.15 & 16.30 & 7.347 & 13.67 & 69.08 & 32.73 & 4.997 & 2.003 \\
\hline K200 & 86.72 & 53.81 & 12.43 & 5.940 & 97.42 & 50.94 & 17.91 & 6.563 & 26.38 & 20.39 & 8.817 & 15.47 & 81.02 & 37.09 & 6.063 & 2.660 \\
\hline K250 & 53.50 & 41.97 & 6.767 & 3.183 & 68.70 & 34.86 & 12.90 & 5.593 & 18.73 & 15.13 & 5.953 & 13.58 & 55.63 & 32.26 & 3.720 & 2.080 \\
\hline LSD & 15.31 & 8.788 & 1.661 & 1.145 & 13.76 & 5.101 & 3.872 & 1.011 & 4.496 & 3.927 & 1.486 & 3.528 & 9.476 & 6.023 & 0.950 & 0.376 \\
\hline Significance & $* *$ & $* *$ & $* *$ & $* *$ & $* *$ & $* *$ & $* *$ & $* *$ & $* *$ & $* *$ & $* *$ & * & $* *$ & $* *$ & $* *$ & $* *$ \\
\hline CV(\%) & 10.94 & 9.11 & 9.33 & 12.73 & 7.66 & 6.08 & 11.59 & 8.75 & 9.32 & 11.04 & 9.07 & 11.20 & 6.10 & 7.90 & 9.27 & 8.59 \\
\hline
\end{tabular}

* Significant at 5\% level of probability, ** significant at $1 \%$ level of probability, $L S D$ least significant difference, $C V$ coefficient of variation 
the fresh weight of bulb per plant. The result was justified by Amin (1998), Talukder (1998), and El-Bassiony (2006). The maximum fresh weight of leaves per plant was observed at $200 \mathrm{~kg} \mathrm{~K} / \mathrm{ha}$, and the minimum fresh weight of leaves per plant was found at control treatment as well as dry weight of leaves (Table 2). It was probably due to favorable conditions availed by the plants for vegetative growth at $200 \mathrm{~kg} \mathrm{k} / \mathrm{ha}$ which possibly enhanced maximum photosynthesis and accumulation of fresh and dry matter in plant. Amin (1998), Talukder (1998), and El-Bassiony (2006) found that higher fresh and dry weight of leaves per plant from $200 \mathrm{~kg} \mathrm{k} / \mathrm{ha}$. Optimum K nutrient supplied from the $200 \mathrm{~kg} \mathrm{k} / \mathrm{ha}$ treatment possibly favored plant growth and development, thus producing wider bulb. Setty and Sulikeri (1989), Uddin (1993), Hossain (1997), Talukder (1998), and El-Bassiony (2006) also found larger bulb from increased $\mathrm{K}$ level up to $200 \mathrm{~kg} \mathrm{k} / \mathrm{ha}$. The highest average number of cloves was obtained in plants grown with $200 \mathrm{~kg} \mathrm{~K} / \mathrm{ha}$ and the lowest number of cloves was found from the control treatment. Talukder (1998) also observed that $\mathrm{K}$ at $200 \mathrm{~kg} \mathrm{k} / \mathrm{ha}$ gave the maximum number of cloves. Increased number of cloves due to sufficient nutrients was achieved possibly due to better growth conditions received by the plants during the course of development. The highest concentration of $\mathrm{N}$ in bulb was observed in $200 \mathrm{~kg} \mathrm{k} / \mathrm{ha}$ (Table 3). A similar result was also reported by El-Bassiony (2006). The results revealed that the maximum $P$ content was found in $200 \mathrm{~kg} \mathrm{k} / \mathrm{ha}$ (Table 3). This result also agreed with the results of El-Bassiony (2006). The $\mathrm{K}$ content in bulb varied from $2.10,2.25,2.50,2.62,2.74,2.82$, and 2.70 due to the application of $\mathrm{K}$ fertilizer. A similar result was also reported by El-Bassiony (2006). Mg content in bulb of garlic did not vary significantly due to the different levels of $\mathrm{K}$ fertilizer. The related result was also reported by El-Bassiony (2006). The highest amount of $\mathrm{N}, \mathrm{P}, \mathrm{K}, \mathrm{Ca}, \mathrm{B}$, and $\mathrm{Na}$ were observed in $200 \mathrm{~kg} \mathrm{k} / \mathrm{ha}$ (Table 3). Only in S, the highest nutrient concentration was found in $150 \mathrm{kh} \mathrm{k} / \mathrm{ha}$. This result also agreed with the results of El-Bassiony (2006).

\section{Summary and conclusion}

A pot experiment was conducted at the net house from November 2007 to March 2008 to evaluate the effect of different $\mathrm{K}$ levels on the plant height, number of leaves per plant, yield contributing characters, macro and micro nutrient content of garlic. Seven different levels of $\mathrm{K}$ were used as a treatment in this experiment and the $\mathrm{K}$ levels were $(0,100,125,150$, 175,200 , and $250 \mathrm{~kg} \mathrm{ha}^{-1}$ ). The fertilizer was used in the form of urea, TSP, MOP, gypsum, boric acid, and zinc sulfate. Appropriate amount of TSP, MOP, gypsum, boric acid, zinc sulfate, and one-third of urea were applied during the final pot preparation. The rest of the urea was divided into two equal halves and were applied at 30 and 60 DAP. Intercultural operations were done whenever necessary in order to support normal crop growth. Five plants were randomly selected to collect the data on plant height, number of leaves, fresh weight of leaves, dry weight of leaves, fresh weight of bulb, dry weight of bulb, bulb diameter, number of cloves, and yield. All the parameters in relation to yield and yield-attributing characters varied significantly due to different doses of $\mathrm{K}$ application but Mg content in bulb was not significant. Potassium alone produced maximum height of plant at treatment $\mathrm{K} 200$ and it was minimum in $\mathrm{K} 0$ at 30, 45, 60, 75, 90, 105 DAP and harvest, respectively.

The application of $\mathrm{K}$ significantly influenced the number of leaves of garlic at 30, 45, 60, 75, 90, 105 DAP and at harvest. The maximum number of leaves was recorded in the treatment of K200. It was observed that at 30 and $45 \mathrm{DAP}$, the number of leaves did not vary significantly. Application of $\mathrm{K}$ alone at different doses induced maximum fresh and dry weight of leaves at the treatment K200 while minimum fresh and dry weight of leaves was obtained in K0 treatment. Fresh and dry weight of garlic bulb varied significantly due to the application of different doses of $\mathrm{K}$. Both the fresh and dry weight of garlic bulb was maximum in $\mathrm{K} 200$ and minimum in $\mathrm{K} 0$. The moisture content of bulb had a significant effect due to different levels of $\mathrm{K}$. Maximum moisture content of leaves was found at K175 and minimum moisture content in $\mathrm{K} 0$ treatment and bulb moisture content was highest in K250 and lowest in K125. The size of the garlic bulb has been measured by interns of diameter of bulb. Potassium induced variation in size. The largest bulb was found in K200 while K0 produced the smallest bulb. The highest number of cloves per bulb was obtained in K200 and lowest number of cloves in $\mathrm{K} 0$ treatment. The application of $\mathrm{K}$ influenced significantly the yield of garlic bulb. Treatment K200 produced the highest garlic bulb yield while lowest yield was obtained in $\mathrm{K} 0$ treatment, respectively. The nutrient contents viz. N, P, K, Ca, S, $\mathrm{B}$, and $\mathrm{Na}$ varied significantly and $\mathrm{Mg}$ content in bulb was not significant due to the application of different doses of $\mathrm{K}$. The highest content was found in K200 while lowest content in $\mathrm{K} 0$ treatment, respectively. The uptake of different nutrients by garlic plant varied significantly due to the different application levels of $\mathrm{K}$. Potassium alone induced maximum uptake of all the elements studied $(\mathrm{N}, \mathrm{P}, \mathrm{K}, \mathrm{S}, \mathrm{Ca}, \mathrm{Mg}, \mathrm{B}$, and $\mathrm{Na})$ at $\mathrm{K}$ at $200 \mathrm{~kg} \mathrm{ha}^{-1}$ and the lowest in $\mathrm{K} 0$ treatment. 


\section{Appendix}

Table 5 Monthly average air temperature, relative humidity and sunshine during experimentation from November, 2007 to March, 2008

\begin{tabular}{lllllllll}
\hline Year & Month & \multicolumn{3}{c}{ Air temperature (OC) } & **Humidity & $\begin{array}{l}\text { *Rainfall } \\
(\mathrm{mm})\end{array}$ & $\begin{array}{l}\text { *Sun } \\
\text { shine } \\
\text { (h) }\end{array}$ \\
\cline { 3 - 6 } & & Max. & Min. & Ave. & & & \\
\hline 2007 & November & 29.71 & 18.49 & 24.10 & 85.07 & 67.0 & 226.30 \\
& December & 26.04 & 13.22 & 19.63 & 83.55 & 00.0 & 202.32 \\
2008 & January & 23.47 & 13.09 & 18.26 & 84.32 & 30.6 & 127.6 \\
& February & 24.94 & 13.81 & 19.37 & 74.03 & 5.4 & 189.4 \\
& March & 29.42 & 20.46 & 24.94 & 80.8 & 95.3 & 164.4 \\
\hline
\end{tabular}

Source: Weather Yard Department of Irrigation and Water Management, Bangladesh Agricultural University, Mymensingh, * Monthly average, ** Monthly total

Table 6 Analysis of variance of plant height of garlic at different DAP due to the different levels of K application

\begin{tabular}{|c|c|c|c|c|c|c|c|c|}
\hline \multirow{2}{*}{$\begin{array}{l}\text { Source of } \\
\text { variation }\end{array}$} & \multirow[t]{2}{*}{$\mathrm{df}$} & \multicolumn{7}{|c|}{ Plant height $(\mathrm{cm})$ at } \\
\hline & & 30 DAP & $45 \mathrm{DAP}$ & $60 \mathrm{DAP}$ & 75 DAP & $90 \mathrm{DAP}$ & 105 DAP & At harvest \\
\hline Treatment & 6 & $1.469 \mathrm{NS}$ & $3.774 \mathrm{NS}$ & $3.734^{*}$ & $17.314^{*}$ & $11.201^{* *}$ & $32.417^{*}$ & $16.614^{* *}$ \\
\hline Error & 14 & 4.026 & 3.173 & 1.370 & 4.385 & 1.270 & 7.548 & 3.700 \\
\hline
\end{tabular}

* Significant at $5 \%$ level of probability, ${ }^{* *}$ Significant at $1 \%$ level of probability, NS not significant

Table 7 Analysis of variance of number of leaves plant ${ }^{-1}$ of garlic at different DAP due to the different levels of $\mathrm{K}$ application

\begin{tabular}{|c|c|c|c|c|c|c|c|c|}
\hline \multirow{2}{*}{$\begin{array}{l}\text { Source of } \\
\text { variation }\end{array}$} & \multirow[t]{2}{*}{ df } & \multicolumn{7}{|c|}{ Number of leaves plant ${ }^{-1}$ at } \\
\hline & & 30 DAP & 45 DAP & 60 DAP & 75 DAP & 90 DAP & 105 DAP & At harvest \\
\hline Treatment & 6 & $0.055 \mathrm{NS}$ & $0.359 \mathrm{NS}$ & $0.403^{*}$ & $0.937^{*}$ & $0.523^{* *}$ & $0.455^{* *}$ & $0.497^{* *}$ \\
\hline Error & 14 & 0.106 & 0.246 & 0.117 & 0.081 & 0.054 & 0.098 & 0.103 \\
\hline
\end{tabular}

* Significant at $5 \%$ level of probability, ** significant at $1 \%$ level of probability, NS not significant

Table 8 Analysis of variance of fresh and dry weight of leaves and bulbs, moisture content, diameter, cloves bulb ${ }^{-1}$ and yield of garlic

\begin{tabular}{|c|c|c|c|c|c|c|c|c|c|c|}
\hline \multirow{2}{*}{$\begin{array}{l}\text { Mean } \\
\text { source of } \\
\text { variation }\end{array}$} & \multirow[t]{2}{*}{ df } & \multicolumn{2}{|c|}{ Fresh weight plant $^{-1}(\mathrm{~g})$} & \multicolumn{2}{|c|}{ Dry weight plant ${ }^{-1}(\mathrm{~g})$} & \multicolumn{2}{|c|}{ Moisture content (\%) } & \multirow{2}{*}{$\begin{array}{l}\text { Diameter } \\
\text { of bulb } \\
(\mathrm{cm})\end{array}$} & \multirow{2}{*}{$\begin{array}{l}\text { Cloves } \\
\text { bulb }^{-1} \\
\text { (No.) }\end{array}$} & \multirow{2}{*}{$\begin{array}{l}\text { Yield } \\
\text { pot }^{-1} \\
\text { (g) }\end{array}$} \\
\hline & & Bulb & Leaves & Bulb & Leaves & Bulb & Leaves & & & \\
\hline Treatment & 6 & $3.898^{* *}$ & $1.728^{* *}$ & $0.394^{* *}$ & $0.134^{*}$ & $22.58^{*}$ & $2.612 \mathrm{NS}$ & $0.461^{*}$ & $13.619^{* *}$ & $56.22^{* *}$ \\
\hline Error & 14 & 0.536 & 0.270 & 0.057 & 0.020 & 20.28 & 14.772 & 0.077 & 1.222 & 6.540 \\
\hline
\end{tabular}

* Significant at $5 \%$ level of probability, ${ }^{* *}$ significant at $1 \%$ level of probability, NS not significant

Table 9 Analysis of variance of N, P, K, S, Ca, Mg, B and Na contents of garlic

\begin{tabular}{|c|c|c|c|c|c|c|c|c|c|c|c|c|c|c|c|c|c|}
\hline \multirow{3}{*}{$\begin{array}{l}\text { Source of } \\
\text { variation }\end{array}$} & \multirow{3}{*}{ df } & \multicolumn{16}{|c|}{ Mean square } \\
\hline & & \multicolumn{2}{|l|}{ N } & \multicolumn{2}{|l|}{$P$} & \multicolumn{2}{|l|}{ K } & \multicolumn{2}{|l|}{ S } & \multicolumn{2}{|l|}{$\mathrm{Ca}$} & \multicolumn{2}{|l|}{$\mathrm{Mg}$} & \multicolumn{2}{|l|}{ B } & \multicolumn{2}{|l|}{$\mathrm{Na}$} \\
\hline & & Bulb & Leaves & Bulb & Leaves & Bulb & Leaves & Bulb & Leaves & Bulb & Leaves & Bulb & Leaves & Bulb & Leaves & Bulb & Leaves \\
\hline Treatment & 6 & $0.447^{* *}$ & $0.327^{* *}$ & $0.017^{* *}$ & $0.015^{* *}$ & $0.215^{* *}$ & $0.635^{* *}$ & $0.003^{* *}$ & $0.036^{* *}$ & $0.010^{* *}$ & $0.102^{* *}$ & $0.001 \mathrm{NS}$ & $0.002^{*}$ & $1.474^{* *}$ & $1.502^{* *}$ & $0.002^{*}$ & $0.002^{*}$ \\
\hline Error & 14 & 0.001 & 0.037 & 0.001 & 0.000 & 0.003 & 0.004 & 0.001 & 0.000 & 0.001 & 0.003 & 0.001 & 0.001 & 0.027 & 0.012 & 0.001 & 0.001 \\
\hline
\end{tabular}

* Significant at $5 \%$ level of probability, ${ }^{* *}$ significant at $1 \%$ level of probability, NS not significant 
Table 10 Analysis of variance of N, P, K, S, Ca, Mg, B and Na uptake of garlic

\begin{tabular}{|c|c|c|c|c|c|c|c|c|c|c|c|c|c|c|c|c|c|}
\hline \multirow{3}{*}{$\begin{array}{l}\text { Source of } \\
\text { variation }\end{array}$} & \multirow[t]{3}{*}{$d f$} & \multicolumn{16}{|c|}{ Mean square } \\
\hline & & \multicolumn{2}{|l|}{$\mathrm{N}$} & \multicolumn{2}{|l|}{ P } & \multicolumn{2}{|l|}{ K } & \multicolumn{2}{|l|}{ S } & \multicolumn{2}{|l|}{$\mathrm{Ca}$} & \multicolumn{2}{|l|}{$\mathrm{Mg}$} & \multicolumn{2}{|l|}{ B } & \multicolumn{2}{|l|}{$\mathrm{Na}$} \\
\hline & & Bulb & Leaves & Bulb & Leaves & Bulb & Leaves & Bulb & Leaves & Bulb & Leaves & Bulb & Leaves & Bulb & Leaves & Bulb & Leaves \\
\hline Treatment & 6 & $920.67^{* * *}$ & $167.76^{* *}$ & $27.50^{* *}$ & $4.06^{* *}$ & $717.69^{* *}$ & $219.46^{* *}$ & $16.01^{* *}$ & $7.91^{* *}$ & $41.13^{* *}$ & $34.96^{* *}$ & $4.18^{* *}$ & $6.52^{*}$ & $301.03^{* *}$ & $28.96^{* *}$ & $4.04^{*}$ & $0.74^{* *}$ \\
\hline Error & 14 & 39.690 & 13.073 & 0.467 & 0.222 & 32.053 & 4.404 & 2.538 & 0.137 & 3.422 & 2.610 & 0.374 & 2.107 & 15.200 & 6.140 & 0.153 & 0.024 \\
\hline
\end{tabular}

* Significant at $5 \%$ level of probability, ${ }^{* *}$ significant at $1 \%$ level of probability

\section{Abbreviations}

DAP: Days after planting; DAS: Days after seedling

\section{Acknowledgments}

The authors are thankful to the Department of Agricultural Chemistry, Bangladesh Agricultural University for the provision of laboratory facilities to carry out this research the experimental samples.

\section{Authors' contributions}

Conceptualization, data curation, writing — original draft preparation-MASJ; writing - review and Editing-MASJ, AS, MA, MAR, MAA; Supervision-AS; data analysis and visualization-A S, RKG, S R S. All authors revised, read, and approved the final manuscript.

\section{Funding}

There are currently no funding sources in the design of the study and collection, analysis, and interpretation of data, and in writing the manuscript.

\section{Availability of data and materials}

The datasets generated and/or analyzed during the current study are included in this study.

\section{Ethics approval and consent to participate}

Not applicable.

\section{Consent for publication}

Not applicable.

\section{Competing interests}

The authors declare that they have no competing interests.

\section{Author details}

${ }^{1}$ Institute of Environment and Sustainable Development in Agriculture, Chinese Academy of Agricultural Science, Beijing, China. 'Department of Agricultural Chemistry, Bangladesh Agricultural University, Mymensingh 2202, Bangladesh. ${ }^{3}$ Institute of Crop Sciences, Chinese Academy of Agricultural Science, Beijing 100081, China. ${ }^{4}$ Institute of Agricultural Resources and Regional Planning, Chinese Academy of Agricultural Science, Beijing 100081, China. ${ }^{5}$ Department of Horticulture, Bangladesh Agricultural University, Mymensingh 2202, Bangladesh.

Received: 1 November 2019 Accepted: 8 January 2020

Published online: 17 January 2020

\section{References}

Al-Moshile AM (2001) Effect of nitrogen, phosphorus and potassium fertilizers on onion productivity in central region of Saudi Arabia. Assiut J Agric Sci 32: 291-305

Amin M R. Effects of different levels of nitrogen and potassium on the growth and yield of garlic. M.S. Thesis, Dept. of Horticulture, BAU, Mymensingh. 1998; 79 p.

Bertoni G (1988) Morard du I, Espagnacq P. Dynamique de l'absortion des elements mineraux I'ail (Allium sativum L.). Agrochimica. 32(5-6):519-530

Black C A Methods of soil analysis. Part-II. Amer. Soc. Agron. Inc. Medison, Washington, USA, 1965; 999-1009, 1487-1492.

Bose T K, Som M G. Vegetable Crops in India, 1st edn., Naya Prakash, Calcutta, India, 1990; 583-601.

Brady N C. The Nature and Properties of Soils. Pentice Hall of India Pvt. Ltd., New Delhi, 1995; p369.
Bybordi A, Malakouti MJ (2003) The effect of various rates of potassium, zinc and copper on the yield and quality of onion under saline conditions in two major onion growing regions of east Azarbayjan. Agric Sci Technol 17:43-52

El-Bassiony, A.M. (2006). Effect of potassium fertilization on growth, yield and quality of onion plants. J. App. Sci. Res. 2(10): 780-785.

FAO. The market for non-traditional agricultural exports. FAO commodities and trade technical paper 2004;3.

Ghosh A B, Bajaj J C, Hasan R, Singh D. Soil and water testing method. A laboratory manual division of soil science and agricultural chemistry, |ARI, New Delhi, India. 1983.

Gomez KA, Gomez AA (1984) Statistical procedures for Agricultural Research. John Wiley and Sons, New York, p 680

Hossain M H. Effect of different levels of nitrogen and potash on the growth and yield of garlic. M.S. Thesis, Dept. of Horticulture, BAU, Mymensingh. 1997; p. 36.

Innvista. Garlic. (2005). http://innvista.master.com/texis/master/search.

Jackson ML (1973) Soil Chemical Analysis. Prentice Hall of India Pvt. Ltd, New Delhi, pp 151-154

Jiang Q, Zhang H, Guanghui A I, Jiang Q S, Zhang H L, Gh A I. Application of potassium fertilizer in onion production. China Vegetables. 1998; 4.

Linx A, Niwuzhang ZY (1997) The effect of K source on yield and quality of some vegetable crops. Acta Agricultural Zhe Jiangensis 9:143-148

Mahmoud R, Asmaa. Effect of agricultural treatments of productivity and quality of onion. Ph.D. Thesis, Hort. Dept., Faculty of Agriculture, Ain Shams Univ. Egypt. 1999.

Melzer O, Alt D, Ladebusch H, Burns IG, Bending GD, Mulholland B (1999) Longterm trial with increasing amounts of phosphorus, potassium and magnesium applied to vegetable crops. Acta Hortic 506:29-36

Mendez F, Castellanos JZ, Ojodeagua JL, Reyes SV, Badillo V, Vargas P, Lazcano I (2001) Phosphorus requirements by garlic under fertigation. Better Crops International 15(2):21-23

Page A L, Miller R H, Keeney D R. Methods of Soil Analysis, Part-2. 2nd edn. Amer. Soc. Agron. Inc. Medison, Washington, USA. 1982; pp. 98-765.

Piper G S. Soil and Plant Analysis. Adeliade, Univ. Hanel press, Australia. 1950.

Purseglove J W. Tropical Crops, Monocotyledons. Longman Group Ltd., England, 1985; pp. 262-268.

Setty B S, Sulikeri G S, Hulamani N C. Effect of N, P and K on growth and yield of garlic (Allium sativum L.). Karnata J. Agril Sci, 1989; 2(3):160-164.

Sharma RP (1992) Effect of planting materials, nitrogen and potash on bulb yield of rainy season onion (Allium cepa L.). Indian J Agron 37:268-284

Sharma RP, Datt N, Sharma PK (2003) Combined application of nitrogen, phosphorus, potassium and farmyard manure in onion (Allium cepa L.) under high hills, dry temperate conditions of north-western Himalayas. Indian Agric Sci 73:225-227

Sing SP, Verma AB (2001) Response of onion (Allium cepa L.) to potassium application. Indian J. Agron. 46:182-185

Talukder A F. Effects of different levels of nitrogen and potassium on the growth and yield of garlic planted in different dates. MS Thesis, Dept. Horticulture, BAU, Mymensingh. 1998; $138 \mathrm{p}$.

Talukder AF, Rahim MH, Alam MS (2002) Effect of planting time and different levels of potassium on the growth and yield of garlic. Bangladesh J Training and Develop 15(1/2):175-180

Wolf B (1982) A comprehensive system of leaf analysis and its use of diagnostic crop nutrient status commun. Soil Sci Plant Anal 13(12):1044-1045

Zink FW (1963) Rate of growth and nutrient absorb of late garlic. Proc Am Soc Hort Sci 83:579

\section{Publisher's Note}

Springer Nature remains neutral with regard to jurisdictional claims in published maps and institutional affiliations. 